\title{
Preparing Globally Competent Teachers: A Paradigm Shift for Teacher Education in Ghana
}

\author{
John Kwasi Annan (iD \\ Department of Educational Leadership, University of Education, Winneba, Ghana \\ Correspondence should be addressed to John Kwasi Annan; kwasifaya@gmail.com
}

Received 6 May 2020; Revised 20 June 2020; Accepted 30 August 2020; Published 22 September 2020

Academic Editor: Haoran Xie

Copyright (c) 2020 John Kwasi Annan. This is an open access article distributed under the Creative Commons Attribution License, which permits unrestricted use, distribution, and reproduction in any medium, provided the original work is properly cited.

It is well known that quality and positive school outcomes are determined by teacher competence, sensitivity, and motivation which are summed as teacher quality. The role teachers play in shaping society requires that training of same must be of utmost priority of governments. With reference to the relevance of archival materials, the study relied mostly on observation and secondary sources of data with content analysis on training of teachers in Ghana. This study identified various elements that contribute to the quality of teachers which ultimately increases the quality of education. These included quality assurance of teacher education, initial training of teachers, deployment processes, professional growth, compensation, and regulatory bodies that ensure standards and compliance. The article also found out that low investments in teacher education, allowing nonprofessional graduates to teach, poor living, and working condition are deterrent to teachers from accepting postings to rural and deprived areas; lack of regular and consistent training for professional development and poor motivation packages for teachers are some of the reasons for poor quality in the education delivery at the basic school level. The study then advocates that teachers must be trained strictly by educational institutions only, aptitude test must be used to recruit teachers, intensify curricula reform to address critical thinking skills in teachers, institute regular development training for teachers, and motivate teachers who accept postings to rural areas.

\section{Introduction}

Education is a collective social effort which ensures that every citizen becomes productive and a critical member of the society with a disciplined capacity towards quality life. The value of the educational product depends largely on the quality of the delivery of it [1]. The role of education in determining how an individual spends his adult life is highheld and in the same vein, the long-term benefits of the investments in education yield no dividend to the society particularly and the country at large. High rates of illiteracy in a country only generate socioeconomic cost, and it threatens social and national security. Education, being an overarching element in national development, abounds in the literature [2-6].

The history of education according to Graham [7] and Antwi [8] predates Ghana's independence where the colonial masters needed people as interpreters and clerical subordinates to help facilitate their trading activities of the then established companies. Sustenance of these trading activities necessitated training of people by the colonial masters. Again, as posited by Antwi [8], the entry of missionaries into the country through the coastal area saw the activities of training intensified. The reason been that the missionaries needed educated folks as catechists and caretakers to help spread their message (The gospel) to the rest of the populace [7]. These led to the establishment of formal education which later spread to all the communities on the coast of Ghana (formerly Gold Coast). The government of Ghana sustained the gains of education and extended them to other parts of the country [9]. The government of Ghana continues to pursue frantic efforts to improve the quality of education for its populace by improving education generally. Ghana's education system consists of three levels (10): basic education or first-cycle education which is made up of two years of kindergarten, six years of primary, and three years of 
Junior High School; second-cycle education which also comprises three years of SHS; TVET; or business, agriculture, or apprenticeship work; and tertiary education which consists of colleges of education (COEs) (3 yrs), polytechnics (3/4 yrs), universities ( 4 yrs), and other degree- and diplomaawarding institutions. The Education Bill (11) also saw to the establishment of three new national bodies-National Inspectorate Council (NIC), National Teaching Authority (NTA), and National Council for Curriculum and Assessment (NaCCA). The mandate of these bodies was mainly oversight responsibility of the pretertiary subsector [12].

Ghana's bid to fulfil the Education for All (EFA) policy unveiled a number of policy reforms and social interventions, a move which sought to expand education access for a larger number of school-aged populations. These interventions included Free Compulsory Universal Basic Education (FCUBE), school feeding program, and capitation grants [13]. Coupled with these reforms, educational spending by the government of Ghana has also been encouraging and commendable, and it is above what UNESCO and Global Partnership for Education (GPE) recommend, that is, $6 \%$ of GDP and $20 \%$ of government's expenditure, respectively. Between 2011 and 2015, Ghana spent between $6 \%$ and $8 \%$ of GDP on education, while expenditure as a proportion of government's spending ranged from $21 \%$ to $28 \%$ [14, 15]. According to the Education Sector Performance Report from the MOE, Ghana's expenditure on education as a proportion of its budget and GDP is far more and higher than its compatriots in the ECOWAS region [12].

Despite government's efforts to improve access and quality of education for its populace by increasing expenditure on education and increasing student intake, education quality still remains a daunting challenge. Some commentators are of the view that the deterioration in education quality and gradual decline of pupils' progress might be the result of government's quest to massively expand education to address the issue of access. Access to education without quality is a waste of time and opportunity. Averting the challenge of quality requires reforms in teacher education. According to Altinok et al. [16], the Legatum Institute annual report on country performance for the year 2019 ranked Ghana at the $91^{\text {st }}$ position out of 167 countries as far as quality of higher education including teacher education was concerned. This means that in spite of government's efforts to better the education delivery in Ghana, there is still more to be done. A deeper understanding of teacher quality and its associated improvement strategies is particularly important because the same teachers are the professionals whose responsibility it is to activate learning through the use of pupil-centered pedagogical approach to realise the goals of policy reforms in Ghana. Methods and approaches to teaching are skills that are acquired from initial training which form the underlying objectives and philosophy of instructional practices. Akyeampong [17] stated that students in the training institutions are hardly engaged in active participation and only occasionally asked questions for clarification. Reasons assigned to the adoption of this lecture method of teaching were that it ensured good coverage of the syllabus, in view of the limited time available [18, 19]. Methods teachers use in delivering lessons are more expository than inquiry and do not afford pupils the opportunity to explore and construct their own knowledge and understanding based on what they are familiar with. There is therefore little opportunity for learners to engage in practical and problem-solving activities. Other concerns that impede quality training of teachers are workload which hinders extensive learning experience for teachers. Akyeapmong [17] reiterated that teaching loads were excessive making it unrealistic to achieve its objectives.

Based on the above discourse, the research seeks to ascertain the state of teacher education and training in Ghana with its associated challenges as well as the opportunities that exist and to explore other viable options to improve teacher education for high-standard education delivery in the Ghanaian basic schools.

1.1. Quality Assurance in Teacher Education. UNICEF defines quality education in terms of some five key sectors: what learners bring, environment, content, processes, and outcomes. This understanding by the UNICEF simply touch on adequacy of schools, teaching and learning materials (TLMs), number of children who finish school, and most importantly, the quality of the teacher. There is no point in providing an opportunity for a child to be schooled if the quality to make that child a useful agent in the society is missing in the education provision. Therefore, the ingredient to effective teacher-learner activities as well as the support from stakeholders to ensure that learners acquire the needed skill must be a concern for everyone.

The concept of teacher training quality is a global phenomenon that requires proper understanding, the benefit of which goes for both individuals and nations alike. DarlingHammond [20] indicated that, among all educational resources, teachers' training is especially a critical contributor to educational outcomes and consequently the success of a nation to advance in its sociopolitical environment. Teacher training quality therefore refers to the process of ensuring that training programs are designed in such a way to help prospective teachers to know and understand a wide range of things about teaching and learning and in their social and cultural contexts [20]. This understanding must be applied to complex classroom situations for the benefit of the diverse students. The understanding of this concept is further reiterated by Fullan [21] who claimed that teacher training quality is probably a means of creating awareness in the minds of policy makers and the general public about what it takes to teach effectively both in terms of knowledge and skills that are needed to allow teachers to develop and use what they know to shape the life of students. Darling-Hammond and Bransford [22] also referred to quality teacher training as a means of preparing teachers to play multiple roles and taking their rightful positions in the teachinglearning environment to confidently face the challenging classroom situations. Improving the quality of education worldwide for students suggests that teachers must be trained with the required skill sets, knowledge, and experiences needed for the times [23-26].

Attempts by successive governments to provide greater access to education should not in any way affect the quality of it; otherwise, the purpose of education will be defeated, 
and the populace will only receive education that makes them alien in their own land. Making education more relevant to the needs of society is among the reasons why quality of education was the concern of the World Education Forum held in Dakar, Senegal, in 2000 [27], until recently, however, the international attention centrally focused more on universal primary education, which is also the second Millennium Development Goal [28]. Quality in education according to Asare [29] can be achieved in many ways, and one of the ways is the relationship that exists between the transmitter (teacher) and the recipient (learner). The role of the teacher in knowledge transmission is vital in the knowledge economy era. Quality education delivery is one that involves a trained and motivated teacher who uses child-centered delivery strategies as a tool to facilitate learning. This kind of learning according to Asare [29] occurs in a well-managed classroom, where supervision and discipline ensure effective use of instructional time. According to the UNESCO [28], four strategies are crucial in providing quality teachers for quality education: recruit the best candidate from a pool of applicants, train the teacher well (before and on the job), allocate teachers effectively to disadvantaged areas through proper incentive packages, and reduce teacher attrition through improved working conditions and flexible career progression pathways.

Training of the teacher should therefore be a great concern for all stakeholders [30]. The world is heading to a new economic era called the knowledge economy where competitive advantage is the order of the day [31]. There must be a paradigm shift from the old methods of teaching to a new approach which addresses the very needs of the times we find ourselves. Teacher education must occupy a center stage in the education agenda of governments. The popular axiom "garbage-in, garbage-out" should inform the thinking of policy formulators with regard to teacher training. How are teachers recruited? How are they trained? How are they deployed? What are the modalities to ensure they remain in the profession? The practice where people who do not get admission to the prestigious universities end up in the colleges of education must be a thing of the past, especially in the knowledge-based era. Quality must begin the process of recruitment to retirement of the teacher. Hence, ascertaining teacher quality to ensure high-standard education delivery in the Ghanaian basic schools is not a misplaced priority.

\section{Methods}

The focus of this study is to ascertain the state of teacher education and training in Ghana with its associated challenges as well as the opportunities that exist and to explore other viable options to improve teacher education for high-standard education delivery in the Ghanaian basic schools. Punch [32] was of the view that qualitative research is a study of the interpretation of various concepts, concerns, and processes. Such design is best when observing people, phenomenon, and situations in their natural settings. Yildirim and Simsek [33] also posited that qualitative research is a research type that utilizes observations, interviews, document analyses, and surveys to convey meaning to the researcher. For this study, there was a triangulation approach from two main sources including observation and document analysis as suggested by Creswell [34]. The secondary source of data used was in the form of written documents, articles, and published reports concerning teacher education, and facts were assessed from the internet, official websites, and the offices of the Ministry of Education of Ghana, Ghana Education Service, National Teaching Council, and the Ministry of Finance.

With the benefit of content analysis, the study highlights the state of teacher education in Ghana and some of the critical factors for quality teacher training. The study further draws out the challenges of teacher training from the data gathered. To ensure confirmability, the data, method, and results sections are elaborately described, and raw data and codes are kept by the researcher within the research process.

\section{Review of the Literature}

3.1. Teacher Training in Ghana. As indicated by Kadingdi [35], the only way to maintain quality and effective teacher workforce is to ensure quality at the start of the process of recruitment and the quality of training (preservice and inservice) the recruits receive. The survival of the quality of nation's education depends largely on the kind of training teachers receive during their initial training as well as onthe-job training.

Currently, there are 46 public colleges of education $(\mathrm{CoE})$ in Ghana which provide initial teacher training for Diploma in Basic Education (DBE). All these colleges of education have a national focus even though they are scattered all over the regions in Ghana. Final examinations for the award of diplomas are conducted by the Cape Coast University as an external examining body. However, university of education, Winneba, and the Cape Coast University both run bachelor degree (BED) programs through their departments and faculties. The colleges of education use both generalist and specialist approaches in training teachers. Graduates with DBE (generalists) are prepared for Kindergarten and the Primary (1-6), while the specialist teachers are posted to Junior High Schools (JHS) to handle specialized subjects such as French and Basic Design and Technology. Besides, BED holders with specialized areas are sent to Senior High Schools. Admission to pursue any of these programs is based on the candidate's graduation from a senior high school with the appropriate requirement.

According to the Anamuah-Mensah committee [36], teachers are trained in various institutions in Ghana. There is 3year Diploma in Basic Education for basic school teachers which is offered by the colleges of education (CoE). Also, there is a 2-year program to upgrade teachers with Cert " $A$ " to a diploma level. Besides, one can acquire a bachelors' degree in any of the education universities in Ghana or a one-year postgraduate diploma to become a professional teacher. The proliferation of alternative paths to teacher certification was met with an increase in the demand for teachers.

The concerns over the years have been whether the pathways to teacher education do matter and that whether 
their experiences of teaching differ with different programs and pathways. Supporting this assertion is Rice [37] who stated that the selectivity of the institution a teacher attended has a significant effect on the output as it may partially be a reflection of the cognitive ability of the teacher. According to Baines [38], the alternative pathways to teaching were initially a stopgap strategy to fill vacancies and to replace unqualified individuals when no certified teacher could be found. The challenge has been how to produce teachers who feel better prepared to penetrate the profession and have the intention to remain in the teaching profession for a longer period of time. Darling-Hammond et al. [39] wrote that the growing demand for teachers in a labour market with funding inequalities and deployment problems have led to compromise in entry requirements and overall quality. However, Baines [38] is of the view that many of the alternative programs as well as pathways of teacher preparation actually do nothing to prepare teachers; according to him, such alternatives provided no opportunities for practical teaching and require no internship which renders the teacher deficient for effective delivery. As noted by Asare and Nti [40], today, the alternative paths to teacher education are no longer a second option but have become a mainstream producing high numbers of teachers. The study of teacher education program outcomes is a strategy that may provide new direction for quality discourse. Research suggests that there is low-level teacher training quality in Ghana. Akyeampong [17] suggests the following to be some of the causes of the low-level quality in teacher training in Ghana: excessive workload, limited time allocation for training, overreliance on the expository method of teaching, teaching was more focused on passing examinations than transmitting skills, and knowledge for teaching.

\subsection{In-Service Training (INSET)/Continuous Professional} Development (CPD). Continuous teacher development is pivotal for any country's discourse on labour force and capacity building. Providing growth opportunities for teachers is a sure way to make them relevant for the job market. If teachers are to develop as agents of change, the focus must be on their cognitive, moral, and competence, as well as their pedagogical and management skills. Ensuring a consistent life-long development of the teacher means ensuring that the school system is on its way to achieving "going concern."

According to Glatthorn [41], teacher development is the growth a teacher attains as a result of increased experience over a period of time. Teacher learning has evolved from what it used to be and now goes beyond a mere assembly of teachers to give them instructions to real training that last for a long time to enable teachers acquire the relevance and competence for the knowledge-based labour market [42]. A more lasting form of growth is the one that is achieved on the job (job-embedded). Job-embedded learning is action-oriented learning which occurs in a work-related setting with one's self and with other people, reflecting on their experiences and acquiring new insights $[43,44]$.

Ghana has a well-crafted general philosophy for teacher professional development in its Policy Framework for
Pretertiary Teacher Professional Development and Management Manual [45], which states that

(i) Teacher professional development in Ghana shall reflect the training needs of teachers, recognize, and reward their professional growth and achievements

(ii) Teachers' career advancement shall be based on a planned and managed process in which evidence of professional growth and achievement shall become the basis for career progression and rewards

(iii) Teacher education and training shall comprise preservice and a system of regular in-service starting with an induction program into teaching for all graduating teachers from colleges of education, the universities, and other accredited tertiary institutions [15]

As suggested by Mensah and Addah [46], teacher professional growth is a critical element in revamping educational outcomes and therefore should not be underestimated in building teachers' capacity in the school system. An effective professional development in the likes of what Ghana intends to roll out enables teachers to think and act faster in solving problems with new skills learned through collaborative efforts. Any effective professional development program for teachers is one that sees teaching and learning as a collective venture and not just a mere series of presentations [47]. Darling-Hammond [20] suggests that there is a linkage between higher improved learning outcomes and teacher involvement in consistent formal professional growth programs that is geared towards context-specific pedagogy. This implies that learning is enhanced when teachers are seen as critical stakeholders in advancing new and improved ways of doing the old things which will invariably lead to new results.

The challenge Ghana has with its implementation of continuous professional development is that the good ideas only exist in the paper and in the documents but not in practice. In practice, the focus of Ghana's CPD is geared towards something else. Manu [48] indicated that, in Ghana, INSET mostly focuses on program implementation and helping participants to pass promotion examinations which is a complete deviation from what is set out to do in the PTPDM manual. Such programs are organized by the Ghana National Association of Teachers (GNAT), TED, and regional and district education offices.

3.3. Teacher Deployment in Ghana. Educational quality depends largely on the availability of qualified teachers to teach. One of the critical issues about the availability of teachers is the management of staffing of schools with teachers. Generally speaking, the demand for, and supply of, teachers addresses both the issues of numbers and the relevance [49]. Teacher demand refers to the need of a number of competent teachers to meet an identified shortage in any educational establishment, whereas the supply of teachers relates to the number and distribution of teachers who are willing and available to teach in the school system [50]. The shortage of teachers in Ghana, especially in the 
rural areas, continues to be a border for successive governments. Therefore, cogent policies regarding recruitment and deployment are critical. According to Akyeampong [17], the demand for new teachers in Ghana at the pretertiary level is necessitated by an increase in the school-going age population, the intention of the government to make education accessible to all, high rate of teacher attrition, and the desire to maintain a lower pupil-teacher ratio to maintain quality.

According to the policy framework of the Ghana Education Service's manual for Pretertiary Teacher Professional Development and Management [45], the system of teacher demand and supply is decentralized to the district level. The districts have the responsibility to recruit and retain teachers in accordance with harmonized policy guidelines and regulations by the National Teaching Council (NTC). One of the desperate ways of solving the teacher shortage problem in Ghana was allowing nonprofessional graduates to teach, especially in rural schools. According to Konadu [51], hiring nonprofessional graduates to handle schools in disadvantaged areas was one way of meeting the teeming demand for teachers in Ghana under the National Service Scheme (NSS) and also by transferring excess professional teachers from educational offices back to the classroom. This practice only inflates the number of untrained teachers in the system especially in the private sector. In order to arrest the shortage challenge in schools, the following measures were put in place: (i) organizing a school mapping to ascertain the required teacher supply and deployment levels, (ii) designing new guidelines for staffing of schools, postings, and transfer of teachers at the basic education level, (iii) identifying the subject background and academic levels of teachers for purposes of postings to appropriate levels of schooling, (iv) relying increasingly on national service personnel for the supply of teachers as a short-term solution to the problem of teacher shortages, (v) transferring excess professional teachers from educational offices back to the classroom, and (vi) recruiting untrained teachers to support the system [51].

Ghana continues to do her best to ensure a fair deployment of teachers to all parts of the country, but the problem of equity in terms of numbers, experience, and qualifications still remains a challenge for the government and other policy implementation agencies. In 2006, the Deputy Minister of Education at a study tour of Asia conducted by the African education ministers stated that the pupil-teacher ratio (PTR) in rural and underserved districts is very high, while there is a comparative surplus of teachers in the urban centers. The introduction of capitation grants and school feeding programs among other interventions has led to an increase in the enrolment of pupils in the rural areas. The challenge therefore is how to ensure adequacy in the supply of teachers to meet the expanded enrolment rates.

3.4. Teacher Motivation. The effect of teacher motivation on quality education delivery is unavoidable. Both extrinsic factors (salary, allowances, promotion, and awards) and intrinsic factors (competence, achievements, recognition, and good rapport) have greater impact on teacher motivation [52]. The government of Ghana has over the years implemented policies to improve access and quality at the basic school level, but little effort has been made to motivate the teacher to remain in teaching. The success of education for all is dependent on a motivated, dedicated, and committed teacher. Gatsinzi et al. [53] posited that teachers get highly motivated and satisfied when they are acknowledged, and their services are valued by stakeholders including the school leadership and district leadership, as well as national leadership.

Under the Civil Service Law, 1993 [54], PNDC Law 327, the government, the Ministry of Education, and the Ghana Education Service in 2010 replaced the Ghana universal salary structure (GUSS) with the single spine salary structure (SSSS) which increased teachers' salary by 15 percent as a retention premium for teachers by means of motivating them [55]. Being recognized for good work done is one sure way of motivating teachers. This was a justification for the introduction of best teacher awards by the government of Ghana through the GES in the year 1995.

Most research studies delve much into why teachers have low job satisfaction and motivation, and this has made research into the area of motivation very superficial. More specifically, little research has been conducted into the reason some teachers are able to stay motivated in conditions that others do not consider conducive. This article seeks to find answers to the question what are the employment conditions that are demotivating teachers in public pretertiary schools in Ghana?

\subsection{The Role of the National Teaching Council in Ensuring} Standards. The Act of Parliament, Act 778, in 2008 mandated the establishment of the self-regulatory body for the teaching fraternity. This body was known as the National Teaching Council (NTC) whose main mandate by Act 778 was to formulating standards, registering of teachers, and establishing a licensure regime to ensure high level of professionalism among teachers. Part of its mandate was to promote excellence and professionalism among teachers and managers of schools by ensuring standards in the educational system through effective regulation, implementation, and supervision of teacher education programs, maintaining discipline, providing opportunities for growth, and leading the overall process of transforming education delivery. Although it attempts to provide some standards of practice for the teaching profession, no indication is given on how the supposed standards were derived. The NTC is also mandated by the same act to give a facelift to the professional status of teachers through licensing and registering of teachers in Ghana.

\section{Discussion}

In an attempt to find answers to the research objective, which was to ascertain the state of teacher education and training in Ghana with its associated challenges as well as the opportunities that exist and to explore other viable options to improve teacher education for high-standard education delivery in the Ghanaian basic schools, the consulted body of literature revealed a number of factors as follows: (1) teacher 
training, (2) access to continuous professional development, (3) teacher deployment, and (4) teacher motivation.

4.1. Teacher Training. According to Coultas and Lewin [56], pupils' low academic achievements and low quality of education have shifted focus to the quality of teacher education. The need for a well-trained, committed teacher with adequate knowledge of the subject matter, updated on the latest and new trends in the teaching profession, cannot be ignored. Some challenges over the years have bedeviled teacher training in the country. Some of the challenges were identified as follows: admitting applicants with weak passes into the $\mathrm{CoE}$, lack of coordination among distance-learning providers, inability of the $\mathrm{CoE}$ to produce enough teachers for the basic education, insufficient alternative pathways for training teachers, and insufficient investment in education $[23,29,30,57]$.

Quality of education delivery in a country is as good as the teachers delivering it. The effectiveness of the teacher hinges on two things: the quality of the person recruited and the kind of training given to the recruited. In Ghana, the practice has been that most people apply to the $\mathrm{CoE}$ when they do not get admissions into the universities. To be a teacher was and it is still seen as a second option. Prof Joseph Kingsley Aboagye, Director of the Institute of Education of the University of Cape Coast (UCC), at a conference on teacher education in subSaharan Africa in 2008 suggested that the current aggregate of 24 that qualified students for admission into the training colleges be raised in order to boost the quality of the intake [58]. According to Aboagye [59], the new tertiary status of colleges of education requires that tutors who teach them upgrade their qualifications as well as update their competencies to meet the new demand for tertiary teaching. This is because tutors are expected to adopt interactive and student-centered instructional strategies in teaching so that the teacher trainees will also teach using the same approach. According to Lewin and Stuart [19], a research conducted by the teacher education directorate (TED) under the MOE showed that the focus of learning in the colleges of education was mainly for examination purposes and that made students mere participants and not active members. Such strategy jeopardizes practical teaching which is based on appropriate methodology.

4.2. Professional Development Opportunities. One of the surest ways of ensuring that teachers still stay relevant and upto-date on their professional life is through professional growth opportunities [60]. However, research points out clearly that teacher development lacks the consistency it deserves as well as a thought-out plan in making it achieve its intended purpose after initial training from the colleges of education $[61,62]$. Acheampong and Furlong [30] stated that even if there is any growth program at all, it is in the form of the train-to-train model where head teachers and circuit supervisors are given some form of training and are expected to give the same to their subordinates. Such training workshops normally focus on new reforms or areas of the curriculum which they might have never studied in detail during their initial teacher training programs.
These discrepancies are the cause to low growth in teacher professional competence $[63,64]$.

4.3. Teacher Deployment. On the issue of teacher deployment, Cobbold [65] is of the view that the difficulty in attracting and retaining adequate yet qualified teachers to staff schools continues to be a challenge to successive governments in Ghana. Cobbold continues to state that the challenge to teacher shortage is as a result of high rate of teacher attrition and limited number of teacher training institutions in Ghana. In some cases, poor living and working conditions, as well as increased workload with the demands of several education reforms, deter teachers from accepting postings to rural areas [66]. Hedges [67] posited that teachers posted to rural areas try all means to switch to urban centers even if it is a private school. EMIS report 2012 reveals that teacher surplus at the primary $(1,549)$ and JHS $(21,630)$ can offset the overall teacher shortage for the basic education subsector. Yet, there is still deployment problem at the basic school level. The data analyzed suggested that there are some schools which have oversubscription of teachers whilst other schools are grossly understaffed. The reason accounting for this disparity is the interference of high-ranking officials (both politicians and technocrats).

4.4. Teacher Motivation. The discussion on motivation was derived from the discourse of teacher shortage and efforts to address this shortage. Motivation is a way of sustaining to the passion and enthusiasm of people to achieve greater impact. Teachers are one of the main ingredients in the effort to promote quality education. As change agents, teachers' role is not limited to only the school but in the community at large. It is based on this fact that the motivation of teachers must take center stage in any educational reform if rural folks are to have universal and equal access to educational opportunities. According to Nilsson [68], the World Education Forum which was held in Dakar, 2000, identified that motivation package for teachers starts with respect for the teacher and also having attractive salaries, opportunity for training and development through enhanced study leave and sponsorship programs, access to decent accommodation, and access to social amenities and community support to participate as a member of the community. Gatsinzi et al. [53] suggested that one way of motivating teachers is by recognition. Valuing teachers' work and their commitment to duty by school leadership is a way to uplift the morale of teachers and will lead to change in attitude and behaviour of the teacher [69]. There must be a hierarchical recognition of teachers' work from school to district and regional and national education management.

The need for trained teachers in deprived areas is not about just the numbers, but equally important is ensuring that they are motivated and retained in rural areas, If the incentives of teachers in the deprived areas are improved, they will be motivated to accept postings and stay in these deprived areas where their services are required. The government of Ghana, as part of its efforts to enhance quality education, has implemented policies to improve access and 
quality at the basic level, but lesser attention is being given to teacher motivation which is one of the crucial elements to promote a high sense of teacher motivation, dedication, and commitment to duty and improve teacher retention rate in the deprived districts in the country. According to Bennell and Akyeampong [70], the Ghanaian rural teacher today is grappling with many motivational challenges with the increase in enrolment of pupils which makes them reluctant to accept postings to deprived areas. Akuoku et al. [71] are of the view that the efforts made by the government to ensure equity in teacher distribution to all parts of the country, especially the rural areas, are still not effective. The study also found out that teachers did not feel the professional allowance and the $15 \%$ retention premium that they were given by the government as they were consolidated with their salary. Also, the inconsistency in the payment of car maintenance allowance as well as transfer grants was a demotivating factor for teachers. Sometimes, accommodation for teachers posted to deprived areas are in deplorable state which does not motivate to the teacher Darvas and Balwanz [72] opined that lack of descent accommodation for teachers in deprived areas contributes to the high rate of teacher attrition; this really contributes to the push factors which make most teachers leave their jobs for improved conditions in other jobs. Conditions of service are the benefits one enjoys from the service they are engaged in [73].

\section{Conclusion and Policy Recommendations}

Subsequent to the above observations and findings, the concern of this article is that teacher education and deployment, as well as motivation, in Ghana must be looked at, and necessary modifications and adjustments must be carried out to ensure higher quality in the overall education delivery in the country. It is only through measures like these that would ensure the relevance and consistency in teacher quality and the overall educational quality. The world is now at the era where globalization and internationalization seem to be the order of the day [50]. Providers, programs, course materials, teachers, or students go beyond the national boundaries such that the borders and national protocols are never a blockage [74]. This beyond-border phenomenon is an indication that institutions can now develop globally minded teachers who are equipped with the necessary capacity and competence to meaningfully engage in international discourse.

The study advocates that teachers must be trained strictly by education universities and institutions only and that the government must setup an accreditation system for teacher preparation that gives maximum assurance of quality. There is also the need for a concerted effort of all stakeholders in teacher education such as the National Teaching Council (NTC) and Teacher Education Division (TED) of the Ghana Education Service (GES), as well as agencies and departments, to re-examine the content of teacher education and training that ensures critical thinking skills and effective classroom practices by teachers. This will enhance the competitiveness and the quality in teachers which will position them for the borderless labour market.
Furthermore, teachers must be recruited based on merit, competence, and quality. This can only be possible if the issue of licensure of teachers is tackled with all the energy it deserves. Teachers must be made to take a national employment examination which will function as a screening tool, and those that pass such examinations are then given the license to teach. This will make entry into the teaching field competitive and professional.

The need for regular and consistent upgrading of ones' professional competence and skills (professional development) is another critical area that needs stakeholders' attention. There can be regular postemployment training for recruited teachers which can be done by various headmasters of the schools and the circuit supervisors (CS) of the zone. To reiterate what Mensah and Addah [46] suggested, teacher professional development helps to achieve teaching and learning objectives in the school system and therefore should be given the maximum attention. Certificates can be awarded to participants and can be one of the critical requirements for promotion to the next level on the career ladder.

Next, attracting teachers to every part of the country, especially the rural and deprived areas, has always been a challenge to successive governments in Ghana. The motivation to accept postings to some parts of the country is minimal and therefore tends to deter newly recruited teachers to such communities where their services are needed. Government must have a sustainable policy on motivation for teachers who accept to be in the rural parts of the country. Incentives such as bicycles, motorbikes, bungalows, solar lamps, and, in some cases, some allowances can do the magic to attract teachers.

Lastly, increasing access to education has led to recruiting nonprofessional teachers from institutions other than education universities. The reality is that the number of teachers may increase to address accessibility issues, but the relevance and quality of training of such graduates will thwart the efforts of the government to solve the problem of quality education. The implication is that the school system will end up churning out people who are unprepared for the job market. Ayara [75] supported this claim when he wrote that "the education system has failed, such that schooling provides few (or no) skills."

In conclusion, there must be frantic efforts made by all stakeholders to ensure that the quality of the teacher is not compromised. The quality must start from initial training through to retirement of the teacher, and this would ensure a higher adjustment in relevance and consistency, as well as competitive advantage, in the global market.

\section{Data Availability}

The data that support the findings of this study are available from the corresponding author upon request.

\section{Conflicts of Interest}

The author declares no conflicts of interest regarding the publication of this article. 


\section{Acknowledgments}

The author wishes to thank Dr. Seung Hee Baek, Rev. Dr. William Obeng-Denteh, and Dr. Mrs. Lydia Asare Kyere for their support and encouragement in the form of comments on earlier versions of this article. The author self-financed the study.

\section{References}

[1] M. Barber and M. Mourshed, How the World's Best-Performing School Systems Come Out on Top, McKinsey \& Company, New York, NY, USA, 2007.

[2] J. Husain, "Improving teacher quality, a keyword for improving education facing challenges," The Turkish Online Journal of Educational Technology, vol. 4, no. 1, 2005.

[3] P. Nikoloz, "Globalization theories and their effect on education," IBSU Scientific Journal, vol. 2, no. 3, pp. 77-88, 2009.

[4] A. Shishigu, E. Gemechu, K. Michael, M. Atnafu, and Y. Ayalew, "Policy debate in Ethiopian Teacher education: retrospection and future direction," International Journal of Progressive Education, vol. 13, no. 3, pp. 61-70, 2017.

[5] T. Tadesse, C. E. Manathunga, and R. M. Gillies, "Making sense of quality teaching and learning in higher education in Ethiopia: unfolding existing realities for future promises," Journal of University Teaching \& Learning Practice, vol. 15, no. 1, p. $4,2018$.

[6] W. Tamrat and D. Teferra, "Internationalization of Ethiopian higher education institutions: manifestations of a nascent system," Journal of Studies in International Education, vol. 22, no. 5, pp. 434-453, 2018.

[7] C. K. Graham, The History of Education in Ghana: From the Earliest Times to the Declaration of Independence, Routledge, Abingdon, UK, 1971.

[8] M. K. Antwi, Education: Society and Development in Ghana, p. 23, Unimax Publishers Limited, Jalandhar, Punjab, 1992.

[9] J. A. Fletcher, "A study of the appraisal of mathematics teachers in Ghana" Ph.D Dissertation, Institute of Education, University of London, London, UK, 1997.

[10] Education Act, "The seven hundred and seventy-eight ACT of parliament of the Republic of Ghana," https://sapghana.com/ data/documents/Education-Act-778.pdf, 2008.

[11] Education Bill, "Explanatory memorandum," https://new-ndpcstatic1.s3.amazonaws.com/CACHES/PUBLICATIONS/2016/ 04/16/Education+Bill+Final+10th+November+New.pdf, 2015.

[12] Ministry of Education, Education Sector Performance Report, Ministry of Education, Accra, Ghana, 2015, https://sapghana. $\mathrm{com} /$ data/documents/Education+Sector+Performance+Report+ ESPR+2015_Final.pdf.

[13] R. Osei Darko, A. G. Owusu, F. E. Asem, and R. L. AfutuKotey, Effects of Capitation Grant on Education Outcomes in Ghana, UNICEF, Accra, Ghana, 2009.

[14] MOF, Fiscal Data 2015, MOF, New Delhi, India, 2016, http:// www.mofep.gov.gh/fiscal-data.

[15] MOE, Education Sector Analysis, MOE, Accra, Ghana, 2018, https://sapghana.com/data/documents/Ghana-Education-Sec tor-Analysis-2018.pdf.

[16] N. Altinok, N. Angrist, and H. A. Patrinos, Global Data Set on Education Quality (1965-2015), The World Bank, Washington, DC, USA, 2018.

[17] K. Akyeapmong, Teacher Training in Ghana: Does it Count? Multi-Site Teacher Education Research Project, Centre for International Education, University of Sussex, Brighton, UK, 2003.
[18] J. G. Ampiah, "An investigation of provision of quality basic education in Ghana: a case study of selected schools in the Central Region," Journal of International Cooperation in Education, vol. 11, no. 3, pp. 19-37, 2008.

[19] K. M. Lewin and J. S. Stuart, "Researching teacher education: new perspectives on practice, performance, and policy," MUSTER Synthesis Report, DFID, London, UK, 2003.

[20] L. Darling-Hammond, "Teacher quality and student achievement," Education Policy Analysis Archives, vol. 8, p. 1, 2000.

[21] M. Fullan, Change Forces, Falmer Press, London, UK, 1993.

[22] L. Darling-Hammond and J. Bransford, Preparing Teachers for a Changing World: What Teachers Should Learn and Be able to Do, Jossey-Bass, San Francisco, CA, USA, 2005.

[23] P. Dolton and O. D. Marcenaro-Gutierrez, "If you pay peanuts do you get monkeys? A cross-country analysis of teacher pay and pupil performance," Economic Policy, vol. 26, no. 65, pp. 5-55, 2011.

[24] Eurydice, Quality Assurance in Teacher Education in Europe, European Commission, Brussels, Belgium, 2006.

[25] A. Schleicher, Preparing Teachers and Developing School Leaders for the 21st Century: Lessons from Around the World, OECD, Paris, France, 2012.

[26] A. Wang, A. Coleman, R. Coley, and R. Phelps, Preparing Teachers Around the World, ETS, Princeton, NJ, 2003.

[27] World Education Forum, Dakar Framework for Action, Education for All: Meeting Our Collective Commitments, pp. 26-28, UNESCO, Dakar, Senegal, 2000, http://unesco.org/ images.

[28] UNESCO, "Teaching and learning: achieving quality for all," Education for All Global Monitoring Report, UNESCO, Paris, France, 2014.

[29] K. Asare, "Education: training, retraining, and retaining teachers in Ghana (part 1)," 2009, http://www.modernghana. com/news/211101/1/education-training-retraining-and-retai ning-teache.html.

[30] K. Acheampong and D. Furlong, Ghana: A Baseline Study of the Teacher Education System, Multi-Site Teacher Educational Research Project, Centre for International Education, University of Sussex Institute of Education, Brighton, UK, 2000.

[31] D. E. Bloom, "Mastering globalization: from ideas to action on higher education reform," Globalization: What Issues are at Stake for Universities, University of Laval, Quebec, Canada, 2002.

[32] K. F. Punch, Introduction to Social Research: Quantitative and Qualitative Approaches, Siyasal Kitapevi, Ankara, Turkey, 2005.

[33] A. Yildirim and H. Simsek, Sosyal Bilimlerde Nitel Arastirma Yontemleri [Qualitative Research Methods in the Social Sciences, Seckin, Ankara, Turkey, 2011.

[34] J. W. Creswell, Educational Research: Planning, Conducting, and Evaluating Quantitative and Qualitative Research, Pearson Education, Inc., Boston, MA, USA, 2012.

[35] S. A. Kadingdi, "A study of primary teachers' views about their work in the context of the FCUBE reform in a disadvantaged district of Ghana," Doctoral Dissertation, Institute of Education, University of London, London, UK, 2004.

[36] J. Anamuah-Mensah, "Meeting the challenges of education in the 21st century," Educational Reforms Commission Report, Ministry of Education Youth \& Sports, Accra, Ghana, 2003.

[37] J. K. Rice, Teacher Quality: Understanding the Effectiveness of Teacher Attributes, Economic Policy Institute, Washington, DC, USA, 2003.

[38] L. A. Baines, "The disintegration of teacher preparation," Educational Horizons, vol. 88, no. 3, pp. 152-163, 2010. 
[39] L. Darling-Hammond, R. Chung, and F. Frelow, "Variation in teacher preparation," Journal of Teacher Education, vol. 53, no. 4, pp. 286-302, 2002.

[40] K. B. Asare and S. K. Nti, "Teacher education in Ghana: a contemporary synopsis and matters arising," SAGE Open, vol. 4, no. 2, 2014.

[41] A. Glatthorn, "Teacher development," International Encyclopedia of Teaching and Teacher Education, vol. 2, pp. 412422, 1995.

[42] G. K. T. Oduro and J. Macbeath, "Traditions and tensions in leadership: the Ghanaian experience," Cambridge Journal of Education, vol. 33, no. 3, pp. 441-455, 2003.

[43] M. Cochran-Smith and S. L. Lytle, "Relationships of knowledge and practice: teacher learning in communities," Review of Research in Education, vol. 24, no. 1, pp. 249-305, 1999.

[44] F. H. Wood and F. McQuarrie, "On-the-job learning. New approaches will shape professional learning in the 21st century," Journal of Staff Development, vol. 20, pp. 10-13, 1999.

[45] Ghana Education Service, Pre-Tertiary Teacher Professional Development and Management in Ghana: Policy Framework, Ghana Education Service, Accra, Ghana, 2012.

[46] D. D. Mensah and W. J. Addah, "Teacher professional development: keys to basic school teachers' curriculum practice success in Ghana," British Journal of Education, vol. 4, no. 4, pp. 29-37, 2016.

[47] R. DuFour, R. DuFour, R. Eaker, and T. Many, Learning by Doing: A Handbook for Professional Learning Communities at Work, Solution Tree, Bloomington, IN, USA, 2006.

[48] S. Y. Manu, In-service Education for Teachers (INSET) in Ghana, 1993.

[49] D. K. Mereku, Demand and Supply of Basic School Teachers in Ghana, Department of Mathematics Education, University College of Education of Winneba, Winneba, Ghana, 2000.

[50] P. Santiago, "The labourmarket for teachers," in International Handbook on theEconomics of Education, G. Johnes and J. Johnes, Eds., pp. 522-578, Edward Elgar Publishing Ltd., Cheltenham, UK, 2004.

[51] A. D. Konadu, Improving the Deployment of Teachers: The Ghanaian Experience, UNESCO, International Institute for Educational Planning, Paris, France, 1994.

[52] M. Armstrong, A Handbook of Human Resource Management Practice, Cambridge University Press, Cambridge, UK, 2007.

[53] P. Gatsinzi, J. Role, and L. N. Makewa, "Work and school related variables in teacher motivation in Gasabo District, Rwanda," Journal of Education and Training, vol. 1, no. 2, pp. 262-275, 2014.

[54] Ministry of Education, Report of the Education Commission on Teacher Education in Ghana, Ministry of Education, Accra, Ghana, 1993.

[55] S. Kingful and A. A. Nusenu, "Teacher motivation in senior high schools in Ghana: a case of Ghana senior high school," Journal of Education and Practice, vol. 6, no. 16, pp. 110-121, 2015.

[56] J. C. Coultas and K. M. Lewin, "Who becomes a teacher? The characteristics of student teachers in four countries," International Journal of Educational Development, vol. 22, no. 3-4, pp. 243-260, 2002.

[57] D. Mereku, "Sixty years of teacher education in Ghana: successes, challenges and the way forward." African Journal of Educational Studies in Mathematics and Sciences, vol. 15, no. 2, pp. 69-74, 2019.

[58] Modern Ghana, "Review of entry requirement of teacher training colleges," 2008, https://www.modernghana.com/ news/175546/review-entry-requirement-of-teacher-trainingcoll.html.
[59] J. K. Aboagye, "Teacher education in Ghana: challenges and prospects," in PRINCOF. Developments in Basic Teacher Education in Ghanapp. 141-154, Kumasi, Ghana, 2008.

[60] J. A. Luft and P. W. Hewson, "Research onteacher professional development programs in science," inHandbook of Research in Science Education, N. G. Ledermanand S. K. Abell, Eds., pp. 889-909, Routledge, Abingdon, UK, 2nd edition, 2014.

[61] C. C. Johnson, "Whole-school collaborative sustained professional development and science teacher change: signs of progress," Journal of Science Teacher Education, vol. 18, no. 4, pp. 629-661, 2007.

[62] S. M. Wilson and J. Berne, "Chapter 6: teacher learning and the acquisition of professional knowledge: an examination of research on contemporary professlonal development," Review of Research in Education, vol. 24, no. 1, pp. 173-209, 1999.

[63] J. K. Agbeko, "Pre-service teacher training and its challenges: the current situation in Ghana," NUE Journal of International Education Cooperation, vol. 2, pp. 73-80, 2007.

[64] C. Ameyaw-Ekumf, "Improving teachers' competence and their working conditions through reform of contents, curricula, methods, structures and means of teaching," 2001, http://www. ibe.unesco.org/International/ICE/ministers/Ghana.pdf.

[65] C. Cobbold, "Solving the teacher shortage problem in Ghana: critical perspectives for understanding the issues," Journal of Education and Practice, vol. 6, no. 9, pp. 71-79, 2015.

[66] K. Akyeampong and K. Asante, Teacher Motivation and Incentives: A Profile of Ghana, University of Education Winneba, Winneba, Ghana, 2005.

[67] J. Hedges, "The importance of posting and interaction with the education bureaucracy in becoming a teacher in Ghana," International Journal of Educational Development, vol. 22, no. 3-4, pp. 353-366, 2002.

[68] P. Nilsson, "Education for all: teacher demand and supply in Africa," Education International, Brussels, Belgium, Education International Working Papers No. 12, 2003.

[69] Pinder and C. Craig, Work Motivation in Organizational Behaviour, Prentice-Hall, Upper Saddle River, NJ, USA, 1998.

[70] P. Bennell and K. Akyeampong, Teacher Motivation in Subsaharan Africa and South Asia, Department for International Development, London, UK, 2007.

[71] O. K. Akuoko, P. Dwumah, and W. B. Mahama, "Teacher motivation and quality education delivery: a study of public basic schools in tamale metropolis in ghana," International Journal of Social Science \& Interdisciplinary Research, vol. 1, no. 12, pp. 29-46, 2012.

[72] P. Darvas and D. Balwanz, Basic Education beyond the Millennium Development Goals in Ghana: How Equity in Service Delivery Affects Educational and Learning Outcomes, World Bank, Washington, DC, USA, 2014.

[73] E. A. Agboada and E. Akubia, Model Interview Questions and Answers for Promotion and Selection to Principal, Superintendent, Assistant Director II and I, Deputy Director, Principal, Headmaster or Headmistress, Best Teacher Awards in the Ghana Education Service: Pass Your Promotion without Tears, 2010.

[74] U. Teichler, "The changing debate on internationalisation of higher education," Higher Education, vol. 48, no. 1, pp. 5-26, 2004.

[75] N. N. Ayara, "The paradox of education and economic growth in Nigeria: empirical evidence," Selected Papers for the 2002 Annual Conference, Nigerian Economic Society (NES) Ibadan: Polygraphics Ventures Ltd., Ibadan, Nigeria, 2002. 